\title{
Infestation levels of Varroa destructor and Nosema spp. in africanized bee (Apis mellifera) colonies during the dry season in the semiarid region of Piauí state
}

\author{
Nível de infestação por Varroa destructor e ocorrência de Nosema spp. \\ em colônias de abelhas africanizadas (Apis mellifera) durante o \\ período seco em uma região semiárida do estado do Piauí \\ Jossandra de Jesus Silva do Nascimento ${ }^{1}$, Maria Beatriz Silva Ferreira ${ }^{1}$, \\ Catiana da Conceição Vieira Melquíades ${ }^{2} \odot$, Juliana do Nascimento Bendini ${ }^{1{ }^{*}}$ (]
}

\begin{abstract}
This study aimed to assess infestation levels of the mite Varroa destructor and microspore Nosema spp. in apiaries in the Picos microregion of Piauí state, Brazil, during the dry season. To that end, bees were collected $(\mathrm{n}=31)$ from 19 apiaries between September and October 2016. Infestation levels of the parasites were analyzed at the Laboratory of the Bee Technology Center, an institution affiliated with the Senador Helvídio Nunes de Barros Campus of the Federal University of Piauí. Varroa destructor was identified in $54 \%$ of the colonies, with infestation levels varying from 0 to $10.54 \%$, and an average of $3.31 \% \pm 4.12$. Analysis of Nosema spp. revealed that all the colonies sampled exhibited microsporidia, albeit at low (1 to 1.4 spores/bee) and very low levels ( 0.35 to 0.95 spores/bee) of infestation. Given the relevance of beekeeping in the semiarid region of Piauí, it was concluded that although infestation levels were deemed low, there is a need to regularly monitor the health of colonies in the apiaries.
\end{abstract}

KEYWORDS: Beekeeping; Honey production; Bee health.

\begin{abstract}
RESUMO: Objetivou-se avaliar o nível de infestação do ácaro Varroa destructor e do microsporídio Nosema spp em apiários da microrregiáo de Picos, Piauí, durante o período seco. Foram realizadas coletas de amostras de abelhas $(\mathrm{n}=31)$ em 19 apiários, entre setembro e outubro de 2016. As análises foram realizadas no Laboratório do Centro de Tecnologia Apícola. Observou-se a ocorrência de Varroa destructor em $54 \%$ das colônias, sendo que os níveis de infestação variaram de 0 a $10,54 \%$, com média de 3,31\% $\pm 4,12$. A pesquisa referente à Nosema spp revelou que todas as colônias amostradas apresentavam o microsporídio, no entanto em níveis baixos ( 1 a 1,4 esporos/abelha) e muito baixos ( 0,35 a 0,95 esporos/abelha) de infestação. Considerando a relevância da apicultura para a região semiárida do Piauí, concluiu-se que embora os níveis de infestação tenham sido considerados baixos, ressalta-se a necessidade de monitoramentos periódicos quanto à sanidade das colônias nos apiários.
\end{abstract}

PALAVRAS-CHAVE: Apicultura; Caatinga; Nordeste; Produção de mel; Sanidade Apícola.

\section{INTRODUCTION}

Different biotic and abiotic factors pose a threat to bee health and, indirectly, the maintenance of biodiversity and global food production. Research suggests that losses of bee colonies are frequently associated with interactions between pathogens and other stress factors, including parasites (NAZZI et al., 2012). Among these organisms, Tesovnik et al. (2017) highlight the mite Varroa destructor as a possible co-factor in the decline of global bee populations.
When infesting honeybees, the mite can cause severe losses in bee colonies (Apis mellifera), compromising yield and killing both young and adult bees (WILSON-RICH et al., 2008). According to Tesovnik et al. (2017), it is one of the most common mites in bee colonies and a vector of viruses that cause diseases such as sacbrood, paralysis and wing deformities (KUSTER; BONCRISTIANI; RUEPPELL, 2014). Additionally, Bermejo and García Fernández (1997) reported 
that the stress caused by Varroa destructor parasitism in bees may be linked to the occurrence of nosemosis, a severe and prevalent bee disease caused by microsporidia (Nosema apis and Nosema ceranae), intracellular parasites that infect the midgut epithelial cells of the adult bee hosts Apis mellifera and Apis cerana, respectively (SINPOO et al., 2018).

Bees are infected by Nosema spp. through the ingestion of mature spores, possibly during cleaning activities, contaminated pollen while exchanging food with other bees (trophallaxis) (FORSGREN; FRIES, 2010) or contaminated water (CHEN et al., 2009).

Beekeeping in Brazil is marked by the introduction of the African bee (Apis mellifera scutellata) and crosses between this subspecies and other European breeds introduced on the American continent. These crosses resulted in the Africanized bee (SOUZA; GRAMACHO; CASTAGNINO, 2012), currently used by beekeepers across the country and, according to Message et al. (2012), considered more resistant to different pathogens and parasites than European bees. However, in Brazil, epidemiological surveys are scarce (MESSAGE; TEIXEIRA; DE JONG, 2012), with most studies focusing on the South and Southeast of the country (CARNEIRO et al., 2007, PINTO et al., 2011, PINTO et al., 2012, CARNEIRO et al., 2014, OCTAVIANOSALVADÉ et al., 2017, SCHAFASCHEK et al., 2019).

The dry season in the Brazilian semiarid is characterized by high temperatures, with low rainfall and relative humidity (MELQUÍADES; BENDINI; MOURA, 2020). These factors, combined with the scarcity of floral resources (BENDINI et al., 2021), favor the weakening of bee colonies, which may become more susceptible to pathogen infestation (COTTER et al., 2011). According to the authors, the immune response of these insects is affected by the low availability of essential amino acids and resulting peptide synthesis, with the lack of carbohydrates reducing the availability of the metabolic energy needed for immune system processes.

In Piauí state, beekeeping has provided employment opportunities and income for family-run small and medium-scale beekeeping farms, especially in the semiarid region (VELOSO FILHO et al., 2012). Given that bee diseases can contribute to weakening of the colony, hive abandonment and yield losses in apiaries in the region, monitoring the health of bees in apiaries in semiarid Piauí is important and recommended. In this respect, the present study aimed to assess infestation levels of the mite Varroa destructor and microspore Nosema spp. in apiaries in the Picos microregion of Piauí state during the dry season.

\section{MATERIAL AND METHODS}

Bees were collected from apiaries in the Picos microregion of Piauí, during the dry season (September to October 2016). To that end, prior contact was made with representatives of associations and/or cooperatives in the municipalities of Itainópolis, Jaicós and Massapê in Piauí to provide guidance on the damage caused by the pathogens (Varroa destructor and Nosema spp.) and the importance of monitoring the health of their colonies.

A total of 19 apiaries were sampled in Massapê do Piauí

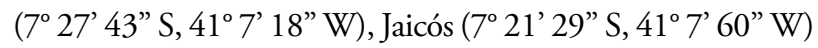
and Itainópolis $\left(7^{\circ} 27^{\prime} 11^{\prime \prime} \mathrm{S}, 41^{\circ} 28^{\prime} 10^{\prime \prime} \mathrm{W}\right)$. Varroa destructor infestation was investigated using the methodology described by Stort et al. (1981), modified by Message (1983). Between 100 and 200 adult bees were collected directly from the center frame of $10 \%$ of the apiaries visited. The samples $(\mathrm{n}=31)$ were stored in sealed transparent jars containing $200 \mathrm{ml}$ of $70 \%$ alcohol, labeled with information on the collection location, name of the beekeeper and apiary number.

At the Laboratory of the Bee Technology Center (CENTAPI), an institution affiliated with the Senador Helvídio Nunes de Barros Campus of the Federal University of Piauí in Picos, each sample was agitated to remove the mites from the bees with the aid of a sieve attached to a PET plastic bottle, so that the bees were retained and the mites fell into a white plastic wash basin to facilitate visualization. Next, the mites and bees were counted separately and the infestation level in each hive was calculated using the following formula: Varroa infestation rate $(\%)=$ (no. of Varroa mites / no. of bees) X 100 .

The same colonies were used to investigate the occurrence of Nosema spp., with the hive entrances sealed using a foam strip. This made it possible to obtain only field bees, frequent hosts of Nosema spp., which were stored in flasks containing 70\% alcohol, totaling 31 samples of at least 60 adult bees per flask.

In the laboratory, the abdomens of the bees were macerated, sieved, filtered and diluted in distilled water to count the spores under an optical microscope (400x) using a Neubauer chamber. The following formula was used: No. of spores per bee $=$ Total no. of spores/ 80) * 4000000 (VALADARES et al., 2016).

The protocol for laboratory diagnostic techniques for bee diseases and pests was used as reference (VALADARES et al., 2016) (Table 1).

\section{RESULTS AND DISCUSSION}

The results of Varroa destructor and Nosema spp. infestation analysis (Table 2) revealed that the mite was detected in 54\% of the colonies and all the apiaries studied were infected by Nosema spp. The levels of infestation did not pose a risk to

Table 1. Level of Nosema spp. infestation in honeybees.

\begin{tabular}{l|c} 
Infestation Level & No. of spores per bee (millions) \\
Null & $<0.01$ \\
\hline Very low & $0.01-1.00$ \\
\hline Low & $1.01-5.00$ \\
\hline Moderate & $5.01-10.00$ \\
\hline Semi-severe & $10.01-20.00$ \\
\hline Severe & $>20.00$ \\
\hline
\end{tabular}


Table 2: Varroa destructor and Nosema spp. infestation levels in African bee colonies in semiarid Piauí.

\begin{tabular}{|c|c|c|c|c|}
\hline Sample & Municipality & $\begin{array}{l}\text { Varroa Infestation } \\
\text { Rate (\%) }\end{array}$ & $\begin{array}{l}\text { Number of Nosema spp. } \\
\text { spores (millions/bee) }\end{array}$ & $\begin{array}{c}\text { Nosema spp. } \\
\text { Infestation Level }\end{array}$ \\
\hline 1 & Itainópolis & 1.35 & 800000 & Very low \\
\hline 2 & Itainópolis & 0.91 & 750000 & Very low \\
\hline 3 & Itainópolis & 2.5 & 900000 & Very low \\
\hline 4 & Itainópolis & 1.1 & 850000 & Very low \\
\hline 5 & Itainópolis & 1.9 & 850000 & Very low \\
\hline 6 & Itainópolis & 4.3 & 900000 & Very low \\
\hline 7 & Itainópolis & 0 & 400000 & Very low \\
\hline 8 & Itainópolis & 5.4 & 1000000 & Very low \\
\hline 9 & Itainópolis & 0 & 750000 & Very low \\
\hline 10 & Itainópolis & 0 & 750000 & Very low \\
\hline 11 & Jaicós & 0 & 500000 & Very low \\
\hline 12 & Jaicós & 0.92 & 800000 & Very low \\
\hline 13 & Jaicós & 0.46 & 600000 & Very low \\
\hline 14 & Jaicós & 0.46 & 600000 & Very low \\
\hline 15 & Massapê do Piauí & 0 & 500000 & Very low \\
\hline 16 & Massapê do Piauí & 0 & 600000 & Very low \\
\hline 17 & Massapê do Piauí & 4.5 & 1250000 & Low \\
\hline 18 & Massapê do Piauí & 0 & 600000 & Very low \\
\hline 19 & Massapê do Piauí & 1.2 & 700000 & Very low \\
\hline 20 & Massapê do Piauí & 6.1 & 950000 & Very low \\
\hline 21 & Massapê do Piauí & 5.6 & 1000000 & Very low \\
\hline 22 & Massapê do Piauí & 19 & 1400000 & Low \\
\hline 23 & Massapê do Piauí & 11.9 & 1200000 & Low \\
\hline 24 & Massapê do Piauí & 0 & 350000 & Very low \\
\hline 25 & Massapê do Piauí & 0 & 400000 & Very low \\
\hline 26 & Massapê do Piauí & 0 & 700000 & Very low \\
\hline 27 & Massapê do Piauí & 0 & 350000 & Very low \\
\hline 28 & Massapê do Piauí & 0 & 900000 & Very low \\
\hline 29 & Massapê do Piauí & 0 & 850000 & Very low \\
\hline 30 & Massapê do Piauí & 0 & 700000 & Very low \\
\hline 31 & Massapê do Piauí & 10.6 & 1000000 & Very low \\
\hline
\end{tabular}

the apiaries since no nosemosis symptoms were observed in the colonies sampled.

\section{Varroa destructor infestation level}

The average mite infestation level recorded in the region studied here $(3.31 \% \pm 4.12)$ is consistent with other investigations carried out in semiarid regions of the states of Pernambuco and Rio Grande do Norte (CLEMENTINO; GALINDO; MILFONT, 2016; MOREIRA et al., 2017) and other regions of the country (PINTO et al., 2011; PINTO et al., 2012; PINTO et al., 2015; WIELEWSKI et al., 2013).
In 27 years of research on the occurrence of Varroa in Brazil, Castilhos et al. (2019) found no evidence of increased infestation in Apis mellifera colonies in the country. Other authors have reported that this pathogen is not a major problem for Brazilian beekeepers.

It is important to note that that the hereditary hygienic behavior of Apis mellifera provides resistance to Varroa destructor (CHERUIYOT et al., 2018). Castagnino, Pinto and Carneiro (2016) also found that, compared to European honeybees (Italian, Caucasian and hybrid), their Africanized counterparts are more efficient at removing dead offspring and are therefore considered more hygienic. The authors emphasized 
that the hygienic behavior of bees is one of their most efficient mechanisms in defending the colony from possible pathogens.

Evangelista et al. (2015) recorded a Varroa destructor infestation level of 0 to $12 \%$ in worker bees and 0 to $18 \%$ in offspring in apiaries from the municipality of Teresina in Piauí state, with an increasing trend in months when less food is available. Santos et al. (2011) highlighted the influence of floral resource availability on Varroa infestation levels in adult bees.

In regard to the results of the present study, the Varroa destructor infestation level was expected to be high during the dry season in the semiarid, largely because the conditions characteristic of this period (scarce floral resources for bees, high temperatures, and low relative humidity). However, $80.64 \%$ of the colonies sampled exhibited an infestation level of 0 to 5 .

\section{Nosema spp. occurrence}

According to Teixeira et al. (2013), the use of molecular techniques to identify individual species from the genus Nosema is relatively recent. As such, species were not identified in this study or most of those surveyed.

Santos et al. (2011) investigated the presence of Nosema spp. in apiaries in different regions of São Paulo state and found that $95.7 \%$ of the colonies were infected, albeit at low levels. In Pernambuco state, Clementino et al. (2015) assessed Nosema spp. infestation and observed moderate to semi-severe levels.

It is important to underscore that Nosema spp. was found in the bees collected from all the hives analyzed and, despite the low infestation levels observed, its presence could significantly reduce colony size, honey production and brood rearing (BOTIAS et al., 2013).

Mariani et al. (2012) confirmed the existence of parasitic interactions between Varroa destructor and Nosema spp. According to Bermejo and García Fernández (1997), the occurrence of Nosema apis may be associated with stress caused by Varroa destructor parasitism in bees. However, Bahreini and Currie (2015) emphasized that a better understanding of interaction between Varroa destructor and Nosema spp. is vital in developing new management strategies to mitigate colony losses. In this respect, linear regression was performed between the number of Varroa destructor mites and number of Nosema spp. spores in the samples collected (Figure 1).

In semiarid Piauí, the correlation coefficient of simple linear regression $(r=0.75)$ revealed a correlation between the

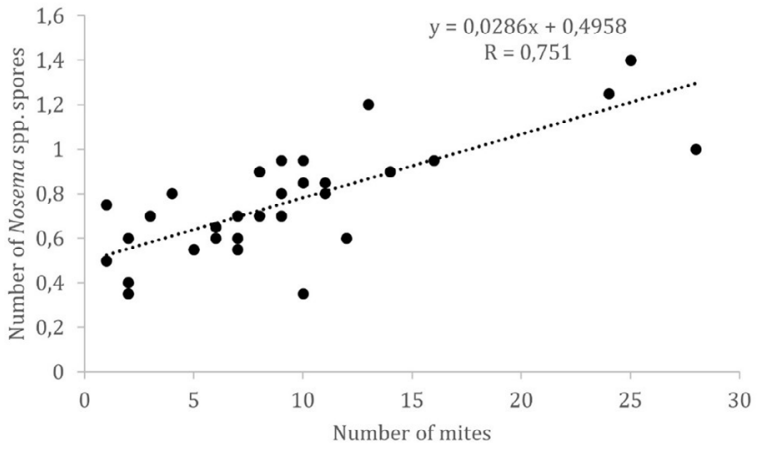

Correlation significant at $1 \%$.

Figure 1. Linear regression between the number of Varroa destructor mites and number of Nosema spp. spores.

variables, demonstrating a trend of positive association between the number of Varroa destructor mites and number of Nosema spp. spores present in the bees and corroborating the findings of Bermejo and García Fernandez (1997) in European bees.

However, Teixeira et al. (2013) emphasized that more information is needed regarding the factors involved in the transmission and survival of this parasite to help clarify its impact on Africanized bee colonies.

As reported in the literature and confirmed in the present study, infestation levels of Varroa destructor and Nosema spp. in apiaries in the semiarid are considered low and can be reduced via prophylactic sanitary measures adopted by beekeepers. The selection and multiplication of colonies with hygienic behavior is an efficient Varroa control measure (CASTAGNINO; PINTO; CARNEIRO, 2016). In this respect, regular inspections, acquiring healthy colonies from reliable sources, the availability of quality water in apiaries and individual drinking fountains in hives are measures that can reduce contamination rates of the disease.

\section{CONCLUSION}

Varroa destructor and Nosema spp. were detected in Africanized bee colonies in the Picos microregion of Piauí state, Brazil. Although the infestation levels recorded were low, there is a need for regular monitoring of bee health in apiaries.

\section{ACKNOWLEDGMENTS}

To the Beekeeping Associations in the Picos region for making their colonies available for this study.

\section{REFERENCES}

BAHREINI, R.; CURRIE, R. W. The influence of Nosema (Microspora: Nosematidae) infection on honey bee (Hymenoptera: Apidae) defense against Varroa destructor (Mesostigmata: Varroidae). Journal of Invertebrate Pathology, v. 132, p. 57-65, 2015.
BENDINI, J. N. et al. Mapping bee flora in honey producing areas of the Alto Médio Canindé microregion in Piauí state, Brazil. Revista Agro@mbiente On-line, v. 15, p. 1-14, 2021. 
BERMEJO, O. F.; GARCÍA FERNANDEZ, P. Nosema disease in the honey bee (Apis mellifera $\mathrm{L}$ ) infested with Varroa mites in southern Spain. Apidologie, v. 28, n. 3-4, p. 105-112, 1997.

BOTIAS, C. et al. Nosema spp. infection and its negative effects on honey bees (Apis mellifera iberiensis) at the colony level. Veterinary Research, v. 44, n. 1, p. 1-15, 2013.

BÜCHLER, R. et al. Evaluation of Traits for the Selection of Apis mellifera for Resistance against Varroa destructor. Insects, v. ll, n. 618 , p. 1-20, 2020

CARNEIRO, F. E.; TORRES, R. R.; STRAPAZZON, R.; RAMIREZ, S. A.; GUERRA JR., J. C. V.; KOLING, D. F.; MORETTO, G. Changes in the Reproductive Ability of the Mite Varroa destructor (Anderson and Trueman) in Africanized Honey Bees (Apis mellifera L.) (Hymenoptera: Apidae) Colonies in Southern Brazil. Neotropical Entomology, v. 36, n. 6, p. 949-952, 2007.

CARNEIRO, F. E. et al. Reproductive ability and level of infestation of the Varroa destructor mite in Apis mellifera apiaries in Blumenau, State of Santa Catarina, Brazil Acta Scientiarum Biological Sciences, v. 36, n. 1, p. 109-112, 2014.

CASTAGNINO, G. L. B.; PINTO, L. F.B.; CARNEIRO, M. R. L. Correlação da infestação de Varroa destructor sobre o comportamento higiênico de abelhas Apis mellifera. Archivos de Zootecnia, v. 65, п. 252, p. 549-554, 2016.

CASTILHOS, D. et al. Bee colony losses in Brazil: a 5-year online survey. Apidologie, v. 50, p. 263-272, 2019.

CHAIMANEE, V. et al. Sperm viability and gene expression in honey bee queens (Apis mellifera) following exposure to the neonicotinoid insecticide imidacloprid and the organophosphate acaricide coumaphos. Journal of insect physiology, v. 89, p. 1-8, 2016.

CHEN, Y.P. et al. Morphological, molecular, and phylogenetic characterization of Nosema ceranae, a microsporidian parasite isolated from the European honey bee, Apis mellifera. Journal of Eukaryotic Microbiology, v. 56, n. 2, p. 142-147, 2009.

CHERUIYOT, S. K. et al. Varroa-specific hygienic behavior of Apis mellifera scutellata in Kenya, Apidologie, v. 49, p. 439-449, 2018.

CLEMENTINO, D. C. et al. Ocorrência da Nosemose em colônias de Apis mellifera L. em apiário no município de Lagoa do Ouro, Microrregião de Garanhuns, Pernambuco. In: CONGRESSO NORDESTINO DE PRODUÇÃO ANIMAL, 2015, Teresina. Anais... Teresina, 2015.

CLEMENTINO, D. C.; GALINDO, G. M.; MILFONT, M. O. Taxa de infestação da Varroa destructor em colônias de Apis mellifera L. no Agreste Meridional de Pernambuco. RevistaVerde deAgroecologia e Desenvolvimento Sustentável, v. 11, n. 3, p. 177-181, 2016.

COTTER, S. C. et al. Macronutrient balance mediates trade-offs between immune function and life history traits. Functional Ecology, v. 25, p. 186-198, 2011.

EVANGELISTA, B. B. C. et al. Avaliação do nível de infestação do ácaro Varroa destructor em colônias de abelhas Apis mellifera $\mathrm{L}$. em Teresina, Piauí. In: CONGRESSO NORDESTINO DE PRODUÇÃO ANIMAL, 2015, Teresina. Anais... Teresina, 2015.

FORSGREN, E.; E FRIES, I. Comparative virulence of Nosema ceranae and Nosema apis in individual European honey bees. Vet. Parasitol, v. 170, p. 212-217, 2010
KUSTER R. D.; BONCRISTIANI H. F.; RUEPPELL O. Immunogene and viral transcript dynamics during parasitic Varroa destructor mite infection of developing honey bee (Apis mellifera) pupae. Journal of Experimental Biology, v. 217, n. 10, p. 1710-8, 2014.

MARIANI, F. et al. Parasitic interactions between nosema spp. and Varroa destructor in Apis mellifera colonies. Zootecnia Tropical, v. 30, n. 1, p. 81-90, 2012

MELQUÍADES, C. C. V.; BENDINI, J. N.; MOURA, S. G. Internal water supply in Africanized beehives during the dry season in the Brazilian semiarid. Revista Agro@mbiente On-line, v. 14, 2020.

MESSAGE, D. Patologia apícola. Informe Agropecuária, v. 9, n. 106, p. 71-76, 1983.

MESSAGE, D.; TEIXEIRA, E. W.; DE JONG, D. Situação da sanidade das abelhas no Brasil. In: FONSECA, V. L. I. et al. (Orgs.). Polinizadores no Brasil: contribuição e perspectivas para a biodiversidade, uso sustentável, conservação e serviços ambientais. São Paulo: Edusp, 2012. p. 237-256.

MORTENSEN, A. N.; JACK, C. J.; ELLIS, J. D. The discovery of Varroa destructor on drone honey bees, Apis mellifera, at drone congregation areas. Parasitology Research, v. 117, p. 3337-3339, 2018.

NAZZI F. et al. Synergistic Parasite-Pathogen Interactions Mediated by Host Immunity Can Drive the Collapse of Honeybee Colonies. PLoS Pathogens, v. 8, n. 6, p. el002735, 2012.

OCTAVIANO-SALVADÉ, C.E. et al. A scientific note on genetic profile of the mite Varroa destructor infesting apiaries in Rio Grande do Sul state, Brazil. Apidologie, v.48, p. 621-622, 2017.

PINTO, F.A. et al. The ectoparasite mite Varroa destructor Anderson and Trueman in southeastern Brazil apiaries: effects of the hygienic behavior of Africanized honey bees on infestation rates. Arquivo Brasileiro de Medicina Veterinária e Zootecnia, v. 64, n. 5, p. 1194-1199, 2012.

PINTO, F. A. et al. Varroa destructor in Juquitiba, Vale do Ribeira, southeastern Brazil: seasonal effects on the infestation rate of ectoparasite mites on honeybees. Sociobiology, v. 57, n. 3, p. 511-518, 2011.

PINTO, F. A. et al. Infestation rate of the mite Varroa destructor in commercial apiaries of the Vale do Paraíba and Serra da Mantiqueira, southeastern Brazil. Arquivo Brasileiro de Medicina Veterinária e Zootecnia, v. 67, n. 2, p. 631-635, 2015.

SANTOS, L. G. et al. Perfil da sanidade apícola em duas regiões do estado de São Paulo, Brasil: apicultura fixa e migratória. Revista de Educação Continuada em Medicina Veterinária e Zootecnia, v. 9, п. 3, p. 60-67, 2011.

SCHAFASCHEK, T. P et al. Infestation and Reproduction of Varroa destructor Anderson and Trueman and Hygienic Behavior in Colonies of Apis mellifera L. (Africanized Honeybee) with Queens of Different Genetic Origins. Sociobiology, 66(3), 448-456, 2019.

SINPOO, C. et al. Impact of Nosema ceranae and Nosema apis on individual worker bees of the two host species (Apis cerana and Apis mellifera) and regulation of host immune response, Journal of Insect Physiology, v. 105, p. 1-8, 2018.

SOUZA, D. A.; GRAMACHO, K. P.; CASTAGNINO, G. L. B. Produtividade de mel e comportamento defensivo como índices de melhoramento genético de abelhas africanizadas (Apis mellifera L.). Revista brasileira de saúde e produção animal, v. 13, n. 2, p. 550-557, 2012. 
STORT, A.C.; GONÇALVES, L.S.; MALASPINA, O. et al. Study on sineacar effectiveness in controlling Varroa jacobsoni. Apidologie, v.12, p.289-297, 1981.

TEIXEIRA, E. W. et al. Nosema ceranae has been present in Brazil for more than three decades infecting Africanized honey bees. Journal of Invertebrate Pathology, v. 114, n. 3, p. 250-254, 2013.

TESOVNIK, T. et al. Immune related gene expression in worker honey bee (Apis mellifera carnica) pupae exposed to neonicotinoid thiamethoxam and Varroa mites (Varroa destructor). PLoS ONE, v. 12, п. 10, p. e0187079, 2017.
VALLADARES, A. et al. (Org.). Protocolo de técnicas laboratoriales de diagnóstico para enfermedades y plagas apícolas. Disponível em: www.oirsa.org. Consulta em: 12-jan-2016.

VELOSO FILHO, F. A. et al. A importância da cooperação produtiva nos arranjos produtivos do mel piauiense: caso Simplício Mendes. Informe econômico, v. 12, n. 28, p. 33- 39, 2012.

WIELEWSKI, P. et al. Níveis de Infestação do Ácaro Varroa destructor em Colônias de Abelhas Apis mellifera L. Africanizadas Submetidas à Produção de Geléia Real ou Rainhas. Magistra, v. 25, n. 1, p. 14-23, 2013. 